\title{
From Maputo to Malabo: Public Agricultural Spending and Food Security in Africa
}

\author{
Charlotte FONTAN SERS \\ Mazhar MUGHAL (mazhar.mughal@esc-pau.fr) \\ Pau Business School, France
}

\begin{abstract}
Africa is the world's biggest battleground in the fight against hunger. African governments and the international development community have increasingly focused on finding ways and means to end hunger and ensure the right to food to the continent's burgeoning population. Public spending on agriculture is one such measure. This study examines the role government spending on agriculture has played in enhancing Africa's state of food security during the past 25 years.

We examine whether this relationship varies over time and space. We explore various aspects of food security and check whether spending on research and development follows the same patterns as the overall public agriculture spending.
\end{abstract}

We find little evidence of significant beneficial effects of public agricultural spending on food security as a whole. However, food security has improved in countries which spend more on agriculture. Spending on agricultural research and development too has shown a useful impact on Africa's food security. There also exists some evidence in favour of public spending's size and time effects.

We conclude that the commitment by African government in the Maputo Declaration to allocate $10 \%$ of public spending to agriculture appears to be pertinent.

JEL Classifications: 011, 055, Q18

Keywords: public agricultural spending; food security; undernutrition; Africa. 


\section{Résumé}

L'Afrique est particulièrement concernée par le problème de la faim. Les gouvernements africains et la Communauté internationale ont intensifié leurs efforts pour améliorer la situation en matière de sécurité alimentaire et assurer le droit à l'alimentation face à une population grandissante. Parmi les mesures prises, un accent particulier a été mis sur les dépenses publiques agricoles. Cette étude cherche à mesurer l'impact des dépenses publiques agricoles sur la sécurité alimentaire en Afrique sur les 25 dernières années.

A travers les estimations effectuées, il s'agit de voir si la relation entre les dépenses publiques agricoles et la sécurité alimentaire varie dans le temps et dans l'espace. Différentes mesures de la sécurité alimentaire sont prises en compte. De plus, il s'agit de voir si les dépenses en faveur de la recherche et développement ont le meme impact que les dépenses publiques agricoles totales.

Les résultats indiquent que dans l'ensemble les dépenses publiques agricoles n'ont pas eu d'effet significatif sur l'évolution de la sécurité alimentaire. Cependant, la situation en matière de sécurité alimentaire s'est améliorée pour les pays qui ont dépensé plus d'argent que la moyenne en faveur de l'agriculture. De plus, les dépenses publiques pour la recherche et développement ont un effet positif sur la sécurité alimentaire. Les résultats indiquent un effet de taille et de temps des dépenses publiques.

Pour conclure, l'engagement pris par les gouvernements africains lors de la conference de Maputo de consacrer 10\% de ses dépenses à l'agriculture apparaît donc comme pertinent. Mots clés : dépenses publiques agricoles ; sécurité alimentaire ; sous-nutrition ; Afrique. 


\section{Introduction}

The potential of agriculture to develop Africa has been increasingly realized in the policy circles. At the 2003 African Union summit in Maputo, Mozambique, African leaders adopted the Comprehensive Africa Agriculture Development Programme (CAADP). The initiative was aimed at promoting agricultural growth, reducing poverty and improving food security in the continent (African Union, 2003). African heads of states committed to allocate at least $10 \%$ of the total government expenditure to the agriculture sector within five years. This level of investment was deemed necessary to achieve an average $6 \%$ annual agricultural growth rate and attain the Millennium Development Goal (MDG) of eradicating extreme hunger and poverty by $2015^{1}$. This commitment was reaffirmed in the 2014 Malabo Declaration on Accelerated Agricultural Growth And Transformation for Shared Prosperity And Improved Livelihoods adopted at the African Union summit at Malabo, Equatorial Guinea. The declaration committed to ending hunger and halving poverty in the continent through inclusive agricultural growth by 2025 (African Union, 2014).

Fourteen years since the Maputo declaration, significant progress has been made in allocating higher public funds to agriculture. 11 African countries managed to allocate $10 \%$ or more of their budgets to agriculture in any year since 2005, while Ethiopia, Kenya, Mozambique and Sierra Leone achieved 6\% agricultural growth in most of these years (World Bank, 2015). Progress has also been made in reducing hunger from the continent even though a quarter of Sub-Saharan Africa's population is still considered undernourished (FAO et al., 2017).

Does this reduction in undernourishment seen in Africa owe in any degree to the greater emphasis laid on higher public spending on agriculture? Is this improvement in food security mainly seen among countries who allocate higher share of their budgets to agriculture? Has the association varied over time and space?

\footnotetext{
${ }^{1}$ For details on United Nations Millennium Development Goals, see : http://www.un.org/millenniumgoals/
} 
Country studies such as Aidoo et al. (2013), Gezimu Gebre (2012), Matchaya and Chilonda (2012), Magana-Lemus et al. (2016), Muche et al (2014) and Zakari et al. (2014) provide some evidence in this regard.

On the macroeconomic level, FAO suggests public spending allocated to agriculture to be one of the key factors for success in reducing undernourishment and poverty, particularly in the rural areas (FAO, 2012; FAO, IFAD, WFP, 2015). According to FAO, hunger is more prevalent in countries where public agricultural expenditure per worker is lower (FAO, 2012 p. 6).

$63 \%$ of the population of SubSaharan African countries lives in rural areas and depends to a large extent on agriculture (World Bank, 2015). Farmers often lack access to quality seeds, inputs, technology and insurance against natural catastrophes and crop failures. Production in many countries also suffers from civil conflicts and climatic changes (FAO et al., 2017). Burundi, Central African Republic and South Sudan, for instance, have seen ongoing social strife during the recent past and have suffered from widespread hunger.

Increase in government funding on agriculture leading to higher agricultural growth can thus play an important role in improving farm output and alleviating poverty and hunger. This can especially happen when this growth increases returns to labour and generates employment for the poor (FAO, IFAD, WFP, 2012, p.28). Benin and Mogues (2012) consider public spending as "perhaps the single most important policy instrument available to governments of most developing countries for promoting growth and equitable distribution."

In this study, we examine the role government spending on agriculture has played in enhancing Africa's level of food security over the past quarter of a century. We study this relationship by analyzing available data for African countries using a panoply of empirical specifications and controlling for various economic, demographic, institutional, climatic and 
geographical factors that influence the state of food security. We examine the temporal and spatial dimension of this relationship as well as the effect of the size of public spending. We explore various aspects of food security and check whether spending on research and development follows the same patterns as the overall public spending allocated to agriculture. We find little evidence of a significant overall beneficial effect of public agricultural spending on food security in Africa. However, food security has improved in countries and regions which spend more on agriculture. Spending on agricultural research and development too shows some useful impact on Africa's food security. There also exists some evidence in favour of public spending's size and time effects. The results of the study are robust to use of an array of empirical specifications and econometric techniques.

The study is structured as follows: Section 2 presents the trends in government expenditures allocated to agriculture by African governments and describes the food security situation in the continent. Empirical model and data employed are presented in Section 3, followed by discussion of results in Section 4. Robustness measures are reported in Section 5. Conclusions and policy implications are given in the last section.

\section{Overview of public spending on agriculture and food security in Africa}

\subsection{Public Spending on Agriculture}

Throughout the 1980s and the 90s, agriculture remained a low-priority item in the policy agenda of most African countries, as focus was mainly on economic reforms and liberalization of the industrial, finance and other service sectors (Yu et al., 2015). Policy rhetoric shifted during the 2000s with realization of agriculture's potential for leading economic growth and poverty alleviation in Africa. Even though public spending on agriculture still remains low compared with on farm investments (Lowder et al., 2015), efforts 
have since been made to raise agricultural productivity through increased government expenditure accompanied by private sector investments and development assistance from international donors.

Regional organizations across the continent devised joint strategies for promoting agricultural growth through collaboration in information sharing, improvements in physical infrastructure and research and development $(\mathrm{R} \& \mathrm{D})$. Examples in this regard are the Common Agricultural Policy for Economic Community of Central African States, the Agricultural Policy of the West African Economic Community (ECOWAP), and the Regional Agricultural Policy of the Southern African Development Community (SADC). As an example, the implementation of the ECOWAP Agricultural Policy adopted in 2005 by the West African Economic Community ECOWAS is based on the Regional Agricultural Investment Programme, the RAIP (ECOWAS, 2008). The program comprises of four components, the first of which is the «Promotion of strategic projects for food security and food sovereignty"2. Accordingly, all countries have defined their national agricultural investment plans with a strong focus on improving food security (FAO, 2015) ${ }^{3}$.

Agricultural spending by African governments has improved substantially in absolute terms. However, the spending still remains inadequate relative to the total expenditure (Table 1). African countries allocate an average of $6 \%$ of their annual budgets to agriculture, a share far below the $10 \%$ target set at Maputo, and only a fifth of the African countries have reached the $10 \%$ expenditure share target in any year since 2003. Although some countries such as Niger, Burkina Faso, Ethiopia, Malawi and Mali regularly allocated $10 \%$ or more of their budgets to agriculture, populous countries like Nigeria, Cameroon and Democratic Republic of the Congo could not regularly allocate even $5 \%$ of government funds to agriculture. In similar

\footnotetext{
${ }^{2}$ See for details : http://www.ecowas.int/ecowas-sectors/agriculture/

${ }^{3}$ For Senegal for instance, see

$\mathrm{ftp} / / / \mathrm{ftp}$.fao.org/tc/tca/CAADP\%20TT/CAADP\%20Implementation/CAADP\%20Post-

Compact/Investment\%20Plans/National\%20Agricultural\%20Investment\%20Plans/Senegal\%20CAADP\%20Post

-Compact\%20Agricultural\%20Sector\%20Investment\%20Plan.pdf
} 
manner, little clear upward trend can be seen in expenditure shares by region, and regional averages have remained below 10\% during the entire 1990 - 2014 period (Table 1). Likewise, while real per capita public spending on agriculture grew seven-fold in East Asia and the Pacific and four-fold in South Asia, expenditures fell by $25 \%$ in Africa south of the Sahara.

Table 1. Public agricultural expenditures as a share of total spending $(1990-2014)$

Figure 1. Public agricultural expenditures as a share of GDP (1990-2014)

Relative to GDP, spending on agriculture fell in several subregions in Africa during the 1990s but has picked up since the 2000s (figure 1). During the first five years since the launch of CAADP (2003-2008), expenditures grew by a healthy $7.7 \%$ per year at an average (IFPRI, 2017). Growth in agricultural spending halted during the subsequent five years (2008-2013) averaging a dismal $1.3 \%$ per year. Reasons for this slow growth include the spike in food prices during 2007 and drying up of international aid and private investments in the wake of the 2008 global financial crisis.

The best pace of progress was seen in the region of West Africa where public spending grew four-folds to reach $9.7 \%$ of total spending in 2010 . In 2003, this region had the lowest investment rates of all African regions. Barring countries in this region, few African countries have yet achieved agricultural production levels reached in the 1960s (Badiane et al., 2015).

Although the continent as a whole saw the longest period of agricultural growth since independence and agricultural growth in several countries occasionally reached double digits, the performance of many countries has remained weak. Growth has often been volatile and episodes of negative growth have also been reported. At the subregional level, only East Africa registered a healthy growth in spending relative to GDP in the 2008 to 2014 period, while West Africa even suffered a decline in agricultural GDP. To that extent, the objectives of Maputo declaration have still not been attained for many African countries. Besides, the 
impact of CAADP implementation on agriculture expenditure is reported to be generally negative while that on land and labour productivity is mixed (Benin, 2016).

\subsection{State of food insecurity in Africa}

Food security is said to exist when all people at all times have access to sufficient, safe and nutritious food to maintain a healthy and active life (FAO, 1996). The phenomenon integrates four dimensions namely stability, access to food, availability of nutritionally adequate food and biological utilization. These dimensions are proxied by indicators such as average value of food production, road density, evolution of cereal import dependency ratio, prevalence of anemia among children under five years of age or sanitation standards in the country.

Today, SubSaharan Africa and South Asia are the world's two main remaining concentrations of food insecurity. In contrast to Western Asia, Latin America and the Caribbean, progress in combating hunger has been slow in the two regions (FAO, IFAD, WFP, 2015). Prevalence rates of undernourishment in SubSaharan Africa still approach $21 \%$ at an average whereas in North Africa, the rates are close to 8\% (FAO et al. 2017). 31\% of African children in 2016 were estimated to suffer from stunted growth, $7 \%$ were wasted, and $37 \%$ of the women of reproductive age were anemic (FAO et al., 2017).

\section{Table 2. Undernourishment Trends in Africa}

Every fourth undernourished human being in the world comes from Africa south of the Sahara (FAO et al. 2017). The number of malnourished people in the continent has grown from 179 million in the $1999-2001$ period to over 205 million in the $2014-16$ period. All the five regions in Africa saw an absolute increase in the number of malnourished people during the period. Table 2 shows the numbers and proportion of undernourished population for various sub regions of Africa for the 1999-2001 and 2014-16 periods. Eastern and Central Africa still suffer from widespread undernourishment with prevalence rates of 32 and $24.8 \%$ 
respectively.

Although absolute numbers of people suffering from hunger and undernutrition have increased, relative measures show significant improvement. Several African Countries, particularly those in West Africa carried out institutional reforms and took policy measures during the 2000s (for instance Senegal's Cellule de lutte contre la malnutrition or Rwanda's National Nutrition Policy 2007) in order to enable efficient and effective intervention to combat hunger and malnutrition (Malabo Montpellier Panel, 2017a). Collaborative initiatives such as Regional Strategic Analysis and Knowledge Support System (ReSAKKS) helped evaluate and compare progress of African countries in meeting the Malabo 2025 targets for food security through measures such as stunting and wasting among under-five children, exclusive breastfeeding and anemia in women (Covic and Hendriks, 2016; Haddad et al., 2016).

Senegal, Ghana and Rwanda are among the top achievers in terms of improving food security in Africa with over 50\% reduction on Global Hunger Index achieved during the 2000 - 2016 period $^{4}$ (Malabo Montpellier Panel, 2017b). Angola, Cameroon, Ethiopia and Togo also obtained over $40 \%$ reduction during the period.

In countries of West Africa, improvement in diet quality has accompanied increase in calorie consumption (Me-Nsope and Staatz, 2015). Per capita availability of roots and tubers and fruits and vegetables has increased as has the consumption of animal proteins, even though consumption of the latter still remains low by world standards. Part of this diet improvement has come from imported food items such as chicken, Irish potatoes as well as rice. Whereas rice production in West Africa increased from 6.4 million tons in 1992 to over 12 million tons in 2011, imports tripled to almost 10 million from an initial 3.5 million tons in 1992. Africa's average Import Dependency ratio rose from $25.2 \%$ in $1990-92$ to $42 \%$ in $2011-2013$. This

\footnotetext{
${ }^{4}$ Global Hunger Index is calculated by IFPRI and captures different dimensions of hunger : undernourishment, child wasting, child stunting and child mortality.
} 
sharp increase is in part due to the emergence of African middle class with diversified taste for food. Another reason is the national policies during the later part of the twentieth century which favoured cultivation of cash crops for exports at the cost of food and cereals.

\section{Model, methodology and data}

\subsection{Model}

As discussed in the previous section, food security is a multi-dimensional phenomenon whose different dimensions are difficult to take into account. Few studies have empirically examined factors that determine the level of food security on the macroeconomic level. In their 2015 report on the state of food security, Food and Agricultural Organization of the United Nations suggest inclusive growth, social protection in the rural areas, well functioning markets, good governance, price stability, agricultural productivity and small farmer income to be among important factors which help alleviate undernourishment in a country (FAO, IFAD, WFP, 2015). Economic growth, which enhances access to food, assets and resources, particularly for the poor and women and allows them to realize their potential, can strongly affect food security. Growth, while a necessary condition for progress in poverty alleviation and hunger reduction especially in the face of an expanding population, is not sufficient if it does not improve the lives of the poor (FAO, IFAD, WFP, 2015). The FAO study shows that the relationship between GDP growth and food security is positive for developing countries as a whole. This association weakens as the country grows richer.

Inflation too has a strong influence on food security. Food accounts for a proportionally higher share of poor households' budgets, and sudden and large increases in food prices hurt them more (Bora et al., 2010).

Demographic factors too affect food security. Slowing population growth rates and falling infant and child mortality helps improve food security situation by lowering pressures on 
available resources. The availability and access to food could be undermined in the aftermath of weather or climatic shock such as crop failure, famine, food or water shortage.

In this study, we control for these drivers of food security in order to gauge the relationship between public agricultural spending and food security in Africa. We also control for the continent's spatial dispersion. Africa's five geographical regions: North, Centre, West, East and South differ widely in demographic, climatic, topographical and economic characteristics and thereby present varying food security scenario. In our model, Central Africa is taken as the base region among the five African subregions.

Our baseline model is given as:

Undernutrition_prevalence $_{\mathrm{i}, \mathrm{t}}=\mathrm{f} \quad$ gdpag $_{\mathrm{i}, \mathrm{t}}$, gdpgrowth $_{\mathrm{i}, \mathrm{t}}$, inflation $_{\mathrm{i}, \mathrm{t}}, \operatorname{popgrowth}_{\mathrm{i}, \mathrm{t}}$, naturalhazard $d_{i, t}, \quad$ Caadp $_{i, t}, \quad$ northafrica $a_{t}, \quad$ eastafrica $a_{t}$ westafrica $a_{t}$ southernafrica $\left.{ }_{t}\right)$

where 'i' represents the corresponding African country and 't' the year of the observation. The proportion of population suffering from undernutrition is taken as the main food security indicator. Caadp is a binary indicator for the year that the corresponding country began participation in the CAADP.

\subsection{Methodology}

The study proceeds in the following steps:

In the first step, the baseline model is estimated using random and fixed-effect panel data techniques. The random-effects model is found to be more appropriate. The model is estimated using different indicators of public agricultural spending: share of agricultural expenditures in the total government budget (the default indicator), logged amount of public agricultural spending, public agricultural spending as a proportion of GDP, per capita public spending on agriculture, public agricultural spending relative to rural population, and per acre 
public agricultural spending. Alternatively, the model is estimated by including the squared term of the default spending variable.

We also estimate the baseline model regressed on the change in undernutrition levels.

In the second step, we focus on the time dimension by alternately using one, two and threeyear lagged values of public agricultural spending. We interact the spending variable with the caadp time dummy. In addition, we estimate the baseline model for the pre-Maputo and postMaputo as well as the $2004-2008$ and 2009 - 2014 time periods. The first pair of estimations looks for differential impact of public spending on food security before and since the African countries signed the Maputo accord. The second pair divides the post-Maputo declaration period into two five-year subperiods.

In step 3, we take into account possible size effect of public spending by alternately limiting the dataset to above median and top quartile countries in the public agricultural spending distribution. We consider both the relative (with respect to total government spending) and absolute (amount in US dollars) measures of agricultural expenditure.

In step 4, we explore spatial diversity by estimating the baseline model on subsets of countries pertaining to Africa's five regions.

In Step 5, we examine the impact of public agricultural spending on the four aspects of food security namely availability, access, stability and biological utilization. The indicators corresponding to the four aspects include average dietary energy supply adequacy, domestic food price index, domestic food price volatility, and proportion of population using improved sanitation facilities. Health and sanitation conditions may play a significant role in improving 
households' nutrition situation (DeWalt, 1993; Headey, 2013). Enhancements in the share of population having access to improved sanitation reflects better hygienic conditions and greater safety from preventable diseases which helps ameliorate nutritional adequacy.

In Step 6, we consider a crucial subcategory of public expenditures on agriculture, namely research and development (R\&D). Indicators alternately used in place of the default indicator include logged amount of agricultural $R \& D$ spending, share of agricultural $R \& D$ in the country's agricultural GDP, per capita spending on agricultural R\&D and the number of scientists per 1000 farmers. The first of these indicators is also estimated with lags of one, two and three years to account for delayed impact of R\&D spending on the country's food security.

In step 7 , we try additional models as a robustness check by alternately including various additional institutional, social, economic and demographic indicators.

Rule of law is taken as an indicator of the country's institutional quality, while intensity of internal conflict and number of terrorist attacks are used to measure the level of violence facing a country. Conflict is a major factor in the recent deterioration in food security situation in Africa (FAO et al., 2017). 60\% of undernourished humans live in countries facing major violence or internal strife. The proportion of undernourished population is between 1.4 and $4.4 \%$ greater in the 46 countries going through civil conflict.

Another potential determinant of food security is urbanization which has the potential to substantially change the levels of undernutrition in developing countries. Rural households engaged in subsistent farming who are partially or fully self-sufficient become food deficient after migrating to urban slums. 
Another factor examined is the domestic food production whose fluctuations can significantly affect vulnerable segments of the population (Mughal and Fontan Sers, 2018).

In the final step, we estimate the baseline model by employing alternative empirical strategies. We include time and country-fixed effects to account for temporal or spatial heterogeneity. Dynamic panel models such as Arellano and Bond, Generalized Least Squares (GLS) and Blundell and Bond System-Generalized Method of Moments (GMM) are also employed to account for potential endogeneity and autocorrelation of residuals.

We also try instrumenting public agricultural spending with quantity of fertilizers, number of tractors and per capita arable land. The three are found to be weak instruments.

\subsection{Data}

The study covers the period from 1991 to 2014. Estimations are carried out on a useable dataset of 670 observations for a maximum of 37 panels. The definitions and sources of the selected variables are given in Table 3 while Table 4 reports summary statistics of the variables.

Table 3. Data description

Table 4. Summary Statistics

\section{Findings}

\subsection{Public agricultural spending and food security - the relationship}

Table 5 Columns 1 and 2 show fixed-and random-effect panel estimations of the baseline model. The relationship between the share of agricultural expenditures in the total government spending and the prevalence of undernourishment in Africa is found to be insignificant. There is some possibility that this insignificant relationship may be limited to a 
particular indicator of public spending. To check for this possibility, we carry out the estimations by substituting the indicator for public agricultural expenditure by other relevant indicators, namely the amount of public agricultural spending, public agricultural spending to GDP ratio, per capita public agricultural spending, public agricultural spending per rural population and public agricultural spending per surface area. The first of these indicators is an absolute measure of spending while the others are relative measures.

Results (given in Columns 3 to 7 corroborate the initial findings. The association between public agricultural spending and food insecurity remains invariably insignificant.

Column 8 shows results of model estimated for change in the level of undernourishment. The relationship is again insignificant similar to the level-indicator estimations. Besides, there are no signs of a non linear relationship (Column 9).

\section{Table 5. Food security and public agricultural spending indicators}

\subsection{Public agricultural spending and food security - time dimension}

Table 6 Columns 1 to 3 show estimations with public agricultural spending respectively lagged by one, two and three years. The association of all the three lags with undernutrition prevalence is found to be statistically insignificant suggesting that time horizon of public spending apparently does not play a significant role in improving food security in Africa.

Column 4 shows results of the estimation with the spending variable interacted with dummy for participation in the Comprehensive Africa Agriculture Development Programme (CAADP). While the relationship between spending and undernourishment remains insignificant as before, the interaction term is significant at the $1 \%$ significance level with a negative sign indicating that increasing agriculture spending since implementation of CAADP is associated with falling rates of undernutrition levels. 
Columns 5 to 8 report results of estimations carried out on the four subperiods (pre-Maputo, post-Maputo, $2004-2008,2009$ - 2014). The spending variable is found to be insignificant in three out of four estimations. Only the 2004 - 2008 subsample shows a weakly significant association between agriculture spending and undernutrition (Column 7). As mentioned in Section 2.1, budget allocations for agriculture improved in a number of countries after the 2003 Maputo declaration. The fact that much of the world including Africa was enjoying high economic growth also helped. During the 2003-2008 period, annual expenditures by African countries grew by a healthy $7.7 \%$ (IFPRI, 2017).

The emphasis on agriculture waned in the wake of the $2007-2008$ global financial crisis with annual agriculture expenditure averaging a negative $1.3 \%$.

The significant relationship between agriculture spending and undernutrition seen during the $2004-2008$ period points to the possibility of size effect of the agriculture spending.

\section{Table 6. Food security and public agricultural spending - time dimension}

\subsection{Public agricultural spending and food security - Size effect}

Now we examine if the overall insignificant relationship between food security and public spending on agriculture seen so far is applicable on all countries regardless of the size of their budgetary allocations. Countries such as Burkina Faso, Ethiopia, Malawi and Mali allocated substantially high proportion of their annual budgets to agriculture.

Table 7 reports estimations pertaining to subsamples of countries in the above median and top quartile part of the spending distribution. The relationship is found to be insignificant for the default relative indicator (Columns $1-2$ ) but significant for the absolute indicator with a negative sign (Columns $3-4)$. This latter set of results gives tentative support to size effect of 
the agriculture spending as higher amounts spent on agriculture are found to be associated with lower incidence of undernourishment in Africa.

Table 7. Food security and public agricultural spending - Size effect

\subsection{Public agricultural spending and food security - Space dimension}

Region-wise estimations (shown in Table 8) are again found to be mainly insignificant. The relationship is found to be significantly negative for North Africa, a region which allocates a high share of budget to agriculture. The relationship is insignificant for the two laggard regions of Southern and Central Africa.

Table 8. Food security and public agricultural spending - Regional variation

\subsection{Public agricultural spending and food security - Dimensions of food security}

Next we seek answer to the question as to whether the insignificant relationship between food security and public spending on agriculture is valid across various aspects of food security, or is the relationship limited to a particular dimension? Table 9 reports results of estimations pertaining to four aspects of food security, namely availability, access, stability and biological utilization. The four corresponding dependent variables are average dietary energy supply, food price index, domestic food price volatility and percentage of population with access to improved sanitation. The coefficient for public agricultural spending retains its lack of significance in all the four estimations.

Table 9. Food security and public agricultural spending - dimensions of food security

\subsection{Public expenditure on agriculture and food security - R\&D spending}


Finally, we consider the possibility that the effect of agriculture spending may vary by type of public expenditure. We focus on a key spending category, namely agricultural research and development. Columns 1 to 4 of Table 10 show estimations with four indicators of agricultural R\&D namely amount of agricultural budget allocated to $R \& D, R \& D$ spending on agriculture as a share of agricultural GDP, per capita R\&D spending and the number of scientists per 1000 farmers.

Both the amount of R\&D expenditures (Column 1) and the number of scientists (Column 4) show a significant negative association. This beneficial effect on food security is also visible after one and two years of the R\&D spending (Columns $5-6$ ). The relationship turns insignificant beyond the second year (Column 7).

Table 10. Food security and R\&D expenditures

\section{Robustness measures}

\subsection{Public agricultural spending and food security - additional controls}

In addition to the baseline parsimonious model, we estimate a number of models with additional controls. Table 11 Columns 1 to 3 report specifications alternatively including rule of law, conflict intensity and number of terrorist attacks faced by the country. Estimations reported in Columns 4 and 5 allow for the proportion of population living in rural areas and domestic food production. The association between public spending on agriculture and undernutrition invariably remains insignificant regardless of the level of significance of the control variables included.

Table 11. Food security and public agricultural spending - Additional controls

\subsection{Public agricultural spending and food security - Alternative models}


The overall relationship between food security and public expenditure on agriculture has so far been mainly found insignificant. In the following, we carry out various estimations to test the robustness of this finding. We run models to tackle possible issues of heteroscedasticity, serial autocorrelation and endogeneity.

Table 12 Column 1 shows model including time-fixed effects while Column 2 shows estimates including country-fixed effects. These estimations account for the possibility of over-time or cross-sectional variation. Columns 3 to 5 report results of Arellano and Bond, GLS and System-GMM estimations.

In all of these models, the lack of significance of the relationship of interest remains intact.

Table 12. Food security and public agricultural spending - alternative models

\section{Discussion and concluding remarks}

Africa is the world's biggest battleground in the fight against hunger. African governments and the international development community have increasingly focused on finding ways and means to end hunger and ensure the right to food to the continent's burgeoning population. Public spending on agriculture is one of these measures. In this study, we examined the association of expenditure on agriculture allocated by African countries during the past quarter of a century with the progress in combating food insecurity. We employed a number of econometric techniques and carried out a large array of estimations. We fail to find an overall significant beneficial role of these expenditures in the evolution of Africa's overall food security situation. We can be reasonably sure that this lack of significance is not a statistical artifact arising from empirical methodology or an econometric quirk. Moreover, there does not seem to be a time lag beyond which the association with food insecurity turns significant. 
This notwithstanding, we find evidence in favour of a size effect of the amount of public agricultural spending. Countries which allocate high amounts of spending to agriculture are found to improve their food security.

Results taken as a whole would suggest that for the majority of African countries, public spending on agriculture over the past quarter of a century has remained below the levels which would allow a diminution of undernutrition. The recommendation to allocate $10 \%$ of government spending to agriculture seems pertinent.

We also find evidence for some beneficial effect of R\&D spending on agriculture on Africa's food security situation. This highlights the need for better directing the spending towards expenditure items that can reach the segments of population the most in need. In Africa south of the Sahara, R\&D has received more than a 40 per cent increase in government funding during the past decade (IFPRI, 2015). The 2015 FAO, African Development Bank Group, ECOWAS report arguments in favour of steering government spending towards R\&D and the provision of other public goods (e.g. road network, access to water and electricity) rather than subsidizing or supporting private goods (e.g. agricultural equipment, seeds, fertilizers and other inputs). The mantra is "more public goods fewer subsidies" (FAO, ADBG, ECOWAS, 2015). Better targeting of public spending is therefore as important as focusing on increasing existing expenditures.

Here a caveat must be mentioned : the transparency, reliability and quality of data on agricultural expenditures in Africa leaves much to be desired. Mogues et al. (2015) term the public spending statistics a 'Black box'. According to the Open Budget Index from the International Budget Partnership ${ }^{5}$, African countries such as Niger, Egypt, Chad and Equatorial Guinea are among the least transparent in the world in terms of budget declarations. Besides, in spite of NEPAD's recommendation to follow Classification of the

\footnotetext{
${ }^{5}$ For detail, see http://survey.internationalbudget.org/\#rankings.
} 
Function of Government (COFOG), African countries employ a variety of classifications of agricultural spending (Benin and Yu, 2013; Curtis and Adama, 2013; FAO, 2011). This makes comparative analysis cumbersome. Results obtained from the data made available by the SPEED database of IFPRI used in this study should therefore be interpreted with caution.

\section{References}

African Union. (2003). African Union Declaration on Agriculture and Food Security in Africa. Assembly/AU/Decl.4-11 (II).

African Union. (2014). African Union summit 2014, Decisions, Declarations and Resolution in Malabo.

Aidoo, R., Mensah, J. O., \& Tuffour, T. (2013). Determinants of household food security in the Sekyere-Afram Plains District of Ghana. European Scientific Journal, ESJ, 9(21).

Badiane, O., Collins, J., Diao, X., \& Ulimwengu, J. M. (2015). Economic recovery in Africa and its determinants. In Beyond a Middle Income Africa: Transforming African Economies for Sustained Growth with Rising Employment and Incomes. Washington DC: International Food Policy Research Institute (IFPRI).

Benin, S. (2016). Impacts of CAADP on Africa's Agricultural-Led Development (IFPRI Discussion Paper 01553). International Food Policy Research Institute.

Benin, S., \& Mogues, T. (2012). Agricultural and rural public spending in Africa: conclusions and implications. In Public Expenditures for Agricultural and Rural Development in Africa (London : Routledge).

Benin, S., \& Yu, B. (2013). Complying with the Maputo Declaration Target: Trends in Public Agricultural Expenditures and Implications for Pursuit of Optimal Allocation of Public Agricultural Spending (ReSaaks Annual Trends and Outlook Report 2012). International Food Policy Research Institute.

Bora, S., Ceccacci, I., Delgado, C., \& Townsend, R. (2010). Food security and conflict. 
World Development Report background papers.

Covic, N., \& Hendriks, S. (2016). Achieiving a nutrition revolution for Africa: The Road to Healthier Diets and Optimal Nutrition (ReSaaks Annual Trends and Outlook Report). IFPRI.

Curtis, M., \& Adama, D. (2013). What constitutes agriculture spending? Areas of consensus and contention. Action Aid.

De Walt, KM. (1993). Nutrition and the commercialization of agriculture: ten years later., 36, $1407-1416$.

ECOWAS. (2008). Regional Agricultural Policy for West Africa "Make agriculture the lever of regional integration". 12p.

EM-DAT. (2015). The CRED/OFDA International Disaster Database. Université catholique de Louvain-Brussels-Belgium.

FAO. (1996). Rome Declaration on World Food Security and World Food Summit Plan of Action (World Food Summit 13-17 November 1996). Rome: FAO.

FAO. (2012). The State of Food and Agriculture: Investing in Agriculture for a better future. Rome: FAO.

FAO. (2015). Regional Overview of Food Insecurity in Africa, African Food Security Prospects Brighter Than Ever. Rome: FAO.

FAO, African Development Bank Group, \& ECOWAS. (2015). Agricultural growth in West Africa : market and policy drivers (p. 406). Rome.

FAO, IFAD, UNICEF, WFP and WHO. (2017). The State of Food Security and Nutrition in the World 2017. Building resilience for peace and food security (p. 132). Rome: FAO.

FAO, IFAD \& WFP. (2012). The State of Food Insecurity in the World Economic growth is necessary but not sufficient to accelerate reduction of hunger and malnutrition. FAO.

FAO, IFAD, \& WFP. (2015). The State of Food Insecurity in the World 2015. Meeting the 
2015 international hunger targets: taking stock of uneven progress (p. 62). Rome: FAO.

Gezimu Gebre, G. (2012). Determinants of Food Insecurity among Households in Addis Ababa City, Ethiopia. Interdisciplinary Description of Complex Systems, 10(2), 159173. https://doi.org/10.7906/indecs.10.2.9

Haddad, L., Bendech, M.Ag, Eriksen, K., Jallow, I., Ledlie, N., \& Bhatia, K. (2016). Africa's Progress toward Meeting Current Nutrition Targets. In ACHIEVING A NUTRITION REVOLUTION FOR AFRICA: The Road to Healthier Diets and Optimal Nutrition. International Food Policy Research Institute (IFPRI).

Headey, D. D. (2013). Developmental Drivers of Nutritional Change: A Cross-Country Analysis. World Development, 42.

IFPRI. (2017). SPEED DATABASE.

Lowder, S., Carisma, B., \& Skoet, J. (2015). Who Invests How Much in Agriculture in Lowand Middle-Income Countries? An Empirical Review (SSRN Scholarly Paper No. ID 2637352). Rochester, NY: Social Science Research Network. Retrieved from https://papers.ssrn.com/abstract=2637352

Magaña-Lemus, D., Ishdorj, A., Rosson, C. P., \& Lara-Álvarez, J. (2016). Determinants of household food insecurity in Mexico. Agricultural and Food Economics, 4, 10.

Malabo Montpellier Panel. (2017a). Nourished: How Africa Can Build a Future Free from Hunger and Malnutrition (p. 36). ZEF, IFPRI.

Malabo Montpellier Panel. (2017b). Nourished: How Africa Can Build a Future Free from Hunger and Malnutrition. Country Case Studies (Angola, Benin, Burkina Faso, Cameroon, Ethiopia, Ghana, Malawi, Mali, Nigeria, Rwanda, Senegal, Togo, Zambia) 26p. ZEF, IFPRI.

Matchaya, G.C., Chilonda, P. (2012). Estimating effects of Constraints on Food Security in 
Malawi : Policy Lessons from Regressions Quantiles. Applied Econometrics and International Development, 12(2).

Me-Nsope, N., \& Staatz, J. (2015). Changes in Per Capita Food Availability in West Africa: Implications for Agricultural Market Development (Food Security Collaborative Policy Briefs No. 212910). Michigan State University, Department of Agricultural, Food, and Resource Economics.

Mogues, T., Caceres, L., Fernandez, F., \& Mariam B. U. (2015). Reconstructing public expenditure data: Use of classification systems to better measure public spending in agriculture — a Mozambique case study. IFPRI.

Muche, M., Endalew, B., \& Koricho, T. (2014). Determinants of Household Food Security among Southwest Ethiopia Rural Households. Food Science and Technology, 2(7), 93-100.

Mughal, M., \& Fontan Sers, C., (2018). Cereal production and food security in South Asia. Unpublished Manuscript.

World Bank. (2015). World Development Indicators.

World Health Organization. (2013). Essential Nutrition Actions Improving maternal, newborn, infant and young child health and nutrition.

Yu, B., Fan, S., \& Magalhães, E. (2015). Trends and Composition of Public Expenditures: A Global and Regional Perspective (SSRN Scholarly Paper No. ID 2637328). Rochester, NY: Social Science Research Network. Retrieved from https://papers.ssrn.com/abstract=2637328

Zakari, S., Ying, L., \& Song, B. (2014). Factors Influencing Household Food Security in West Africa: The Case of Southern Niger. Sustainability, 6(3), 1191-1202. 
Table 1. Public agricultural expenditures as a share of total spending (\%) 1990 - 2014

\begin{tabular}{c|c|c|c|c|c|}
\hline Subregion & $\mathbf{1 9 9 1 - 1 9 9 5}$ & $\mathbf{1 9 9 6 - 2 0 0 0}$ & $\mathbf{2 0 0 1 - 2 0 0 5}$ & $\mathbf{2 0 0 6 - 2 0 1 0}$ & $\mathbf{2 0 1 1 - 2 0 1 4}$ \\
\hline North Africa & 5,01 & 5,52 & 5,08 & 3,71 & - \\
\hline Central Africa & 1,65 & 4,09 & 1,08 & 1,88 & - \\
\hline East Africa & 5,82 & 5,26 & 5,73 & 7,72 & 5,24 \\
\hline West Africa & 9,14 & 7,91 & 7,05 & 8,91 & - \\
\hline Southern Africa & 6,31 & 5,1 & 3,57 & 3,01 & - \\
\hline
\end{tabular}

Source : SPEED Database (IFPRI, 2017)

Table 2. Undernourishment Trends in Africa

\begin{tabular}{|c|cc|cc|}
\hline Sub Region & $\begin{array}{c}\text { Number of } \\
\text { undernourished } \\
\text { people } \\
\text { (million }\end{array}$ & $\begin{array}{c}\text { Undernourishmen } \\
\text { t prevalence (\%) }\end{array}$ \\
& \multicolumn{2}{|c|}{ ) } & & \\
& $\mathbf{1 9 9 9 -}$ & $\mathbf{2 0 1 4 - 1 6}$ & $\mathbf{1 9 9 9 - 2 0 0 1}$ & $\mathbf{2 0 1 5}$ \\
\hline North Africa & 9,8 & 18,6 & $6,80 \%$ & $8,30 \%$ \\
East Africa & 112,8 & 125,8 & $39,40 \%$ & $32 \%$ \\
Middle Africa & 35,8 & 37,6 & $37.2 \%$ & $24.8 \%$ \\
Southern Africa & 3,7 & 4,4 & $7.1 \%$ & $7 \%$ \\
West Africa & 36,2 & 37,3 & $15.4 \%$ & $10.6 \%$ \\
\hline SubSaharan Africa & $\mathbf{1 7 9 , 1}$ & $\mathbf{2 0 5 , 2}$ & $\mathbf{2 8 , 2}$ & $\mathbf{2 1 , 3}$ \\
\hline
\end{tabular}


Figure 1. Public agricultural expenditures as a share of GDP 1990-2014

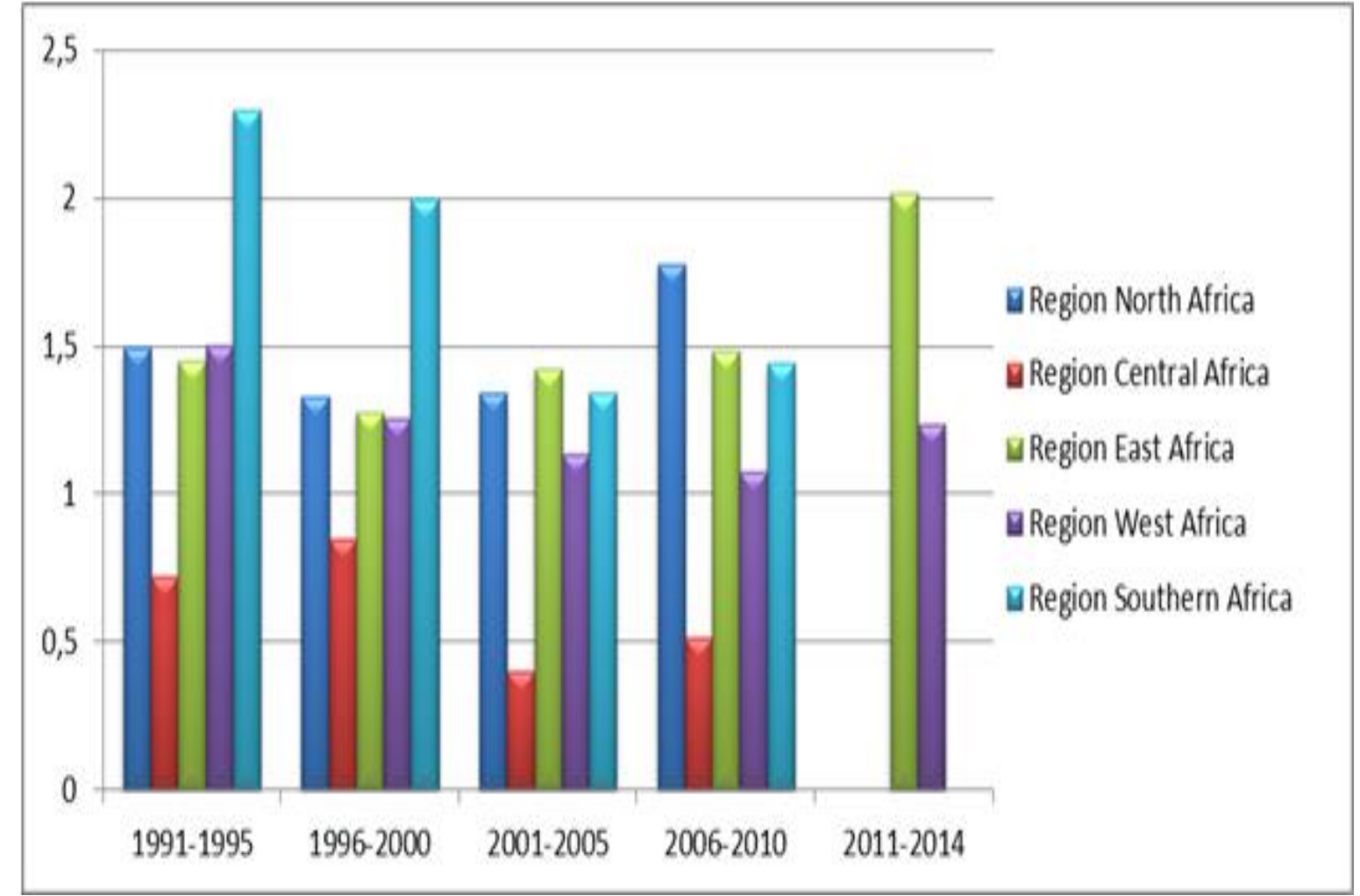

Source : SPEED Database (IFPRI, 2017) 
Table 3. Data description

\begin{tabular}{|c|c|c|}
\hline Variable & Definition & Source \\
\hline \multicolumn{3}{|c|}{ Food security } \\
\hline under_nourishment & Prevalence of undernourishment (\%) (3-year average) & FAOSTAT \\
\hline $\begin{array}{l}\text { Average Dietary Energy Supply } \\
\text { Adequacy }\end{array}$ & Average Dietary Energy Supply Adequacy (ADESA) :\%/ Dimension of Food security for AVAILABILITY & FAOSTAT \\
\hline Food price index & Domestic food price index & FAOSTAT \\
\hline $\begin{array}{l}\text { Per capita food production } \\
\text { variability. }\end{array}$ & Per capita variation in food production, Constant 2004-2006 thousand international \$ & FAOSTAT \\
\hline Sanitation & $\begin{array}{l}\text { Access to improved sanitation facilities refers to the percentage of the population using improved sanitation } \\
\text { facilities. }\end{array}$ & WHO/UNICEF \\
\hline \multicolumn{3}{|c|}{ Public agricultural spending } \\
\hline agshareinspending & Percentage of agriculture in total government spending & IFPRI SPEED database \\
\hline agexp & Agriculture expenditure in 2005 usd (in US \$ & IFPRI SPEED database \\
\hline agexpgdp & Public agricultural spending to GDP & IFPRI SPEED database \\
\hline agexppc & Public agricultural spending per capita & IFPRI SPEED database \\
\hline agexprural & Public agricultural spending per rural population & IFPRI SPEED database \\
\hline agexpland & public agricultural spending per acre & IFPRI SPEED database \\
\hline \multicolumn{3}{|c|}{ Agricultural $R \& D$} \\
\hline agrirespending & Agricultural Research Expenditure. Spending, total (million constant 2011 US \$ dollars) & ASTI \\
\hline agriregdp & Agricultural Research Expenditure as a share of Agricultural GDP & ASTI \\
\hline agrirepc & Agricultural Research Expenditure per capita & ASTI \\
\hline
\end{tabular}




\begin{tabular}{|c|c|c|}
\hline agriresearchers & Researchers, total (FTEs per 100,000 farmers) & ASTI \\
\hline gdpgrowth & Growth of GDP (constant 2010 US \$) & $\begin{array}{l}\text { World Bank national accounts data, and OECD National } \\
\text { Accounts data files. }\end{array}$ \\
\hline inflation & Inflation, consumer prices (annual \%) & $\begin{array}{l}\text { International Monetary Fund, International Financial } \\
\text { Statistics and data files. }\end{array}$ \\
\hline popgrowth & Population growth rate (\%) & $\begin{array}{l}\text { UNICEF, WHO, World Bank, UN DESA Population } \\
\text { Division }\end{array}$ \\
\hline natural_hazard & Number of disasters associated with food shortage, crop failure or famine & Emdat \\
\hline caadp & participation in CAADP (Comprehensive Africa Agriculture Development Programme) & $\mathrm{AU}$ \\
\hline rule_of_law & $\begin{array}{l}\text { Reflects perceptions of the extent to which agents have confidence in and abide by the rules of society, and in } \\
\text { particular the quality of contract enforcement, property rights, the police, and the courts, as well as the likelihood of } \\
\text { crime and violence. }\end{array}$ & World Bank World Development Indicators database \\
\hline attacks & number of terrorist attacks in a given year & Global Terrorism Database \\
\hline intensity_level & level of conflict intensity measured in terms of battle-related deaths in a given year & UCDP PRIO Armed Conflict Dataset \\
\hline rural_pop_share & Proportion of total population living in rural areas & World Bank World Development Indicators database \\
\hline foodproductionindex & Food Production Index & FAOSTAT \\
\hline
\end{tabular}


Table 4. Summary Statistics

\begin{tabular}{|c|c|c|c|c|c|}
\hline VARIABLES & $\mathrm{N}$ & mean & sd & $\min$ & $\max$ \\
\hline \multicolumn{6}{|l|}{ Food security } \\
\hline under_nourishment & 1,074 & 25.31 & 15.38 & 5 & 76.80 \\
\hline Average Dietary Energy Supply Adequacy & 1,056 & 108.5 & 15.87 & 69 & 152 \\
\hline Food price index & 620 & 242.6 & 525.0 & 0.100 & 8,6 \\
\hline Per capita food production variability. & 1,185 & 8.047 & 7.452 & 0.500 & 64 \\
\hline Sanitation & 1,245 & 36.34 & 25.98 & 2.600 & 98.40 \\
\hline \multicolumn{6}{|l|}{ Public agricultural spending } \\
\hline agshareinspending & 794 & 1.274 & 1.182 & 0.00155 & 9.464 \\
\hline agexp & 747 & $1.722 \mathrm{e}+08$ & $2.691 e+08$ & 28.19 & $2.170 \mathrm{e}+09$ \\
\hline agexpgdp & 747 & 0.979 & 0.931 & $2.78 e-07$ & 7.467 \\
\hline agexppc & 747 & 17.56 & 26.50 & $2.22 \mathrm{e}-06$ & 243.4 \\
\hline agexprural & 747 & 32.94 & 55.32 & $3.35 e-06$ & 502.0 \\
\hline agexpland & 700 & 14,083 & 48,286 & 0.000729 & 554,053 \\
\hline \multicolumn{6}{|l|}{ Agricultural R\&D } \\
\hline agrirespending & 593 & 31.43 & 61.10 & 0.100 & 467.8 \\
\hline agriregdp & 541 & 0.996 & 1.045 & 0.100 & 7.400 \\
\hline agrirepc & 533 & 2.349 & 3.049 & 0.0616 & 17.50 \\
\hline agriresearchers & 606 & 19.68 & 46.92 & 1.883 & 342.5 \\
\hline gdpgrowth & 1,331 & 4.257 & 9.119 & -62.08 & 150.0 \\
\hline inflation & 1,214 & 46.79 & 713.3 & -11.69 & 23,773 \\
\hline popgrowth & 1,399 & 2.374 & 1.140 & -7.597 & 10.26 \\
\hline natural_hazard & 1,296 & 0.121 & 0.326 & 0 & 1 \\
\hline rule_of_law & 959 & -0.653 & 0.620 & -2.606 & 1.250 \\
\hline attacks & 444 & 21.92 & 68.14 & 1 & 710 \\
\hline intensity_level & 314 & 1.229 & 0.421 & 1 & 2 \\
\hline rural_pop_share & 1,075 & 61.00 & 16.45 & 13.34 & 94.51 \\
\hline foodproductionindex & 1,343 & 98.92 & 26.97 & 39 & 207.0 \\
\hline
\end{tabular}


Table 5. Food security and public agricultural spending

$$
\text { (1) }
$$

(2)

(3)

$$
\text { (4) }
$$

(5)

(6)

(7)

(8)

(9)

\begin{tabular}{|c|c|c|c|c|c|c|c|c|c|}
\hline agshareinspending & $\begin{array}{l}-0.161 \\
(0.531)\end{array}$ & $\begin{array}{l}-0.130 \\
(0.575)\end{array}$ & & & & & & $\begin{array}{c}0.0980 \\
(0.0603)\end{array}$ & $\begin{array}{c}0.306 \\
(0.938)\end{array}$ \\
\hline Inagexp & & & $\begin{array}{l}-1.284 \\
(1.009)\end{array}$ & & & & & & \\
\hline agexpgdp & & & & $\begin{array}{c}0.118 \\
(0.772)\end{array}$ & & & & & \\
\hline agexppc & & & & & $\begin{array}{l}-0.0383 \\
(0.0647)\end{array}$ & & & & \\
\hline agexprural & & & & & & $\begin{array}{l}-0.0203 \\
(0.0278)\end{array}$ & & & \\
\hline Inagexpland & & & & & & & $\begin{array}{l}-1.587 \\
(1.113)\end{array}$ & & \\
\hline sq gdpag_ppp & & & & & & & & & $\begin{array}{l}-0.0714 \\
(0.108)\end{array}$ \\
\hline gdpgrowth & $\begin{array}{c}-0.223^{* *} \\
(0.103)\end{array}$ & $\begin{array}{c}-0.225^{* *} \\
(0.104)\end{array}$ & $\begin{array}{l}-0.213^{* *} \\
(0.0956)\end{array}$ & $\begin{array}{c}-0.229^{* *} \\
(0.104)\end{array}$ & $\begin{array}{c}-0.228^{* *} \\
(0.102)\end{array}$ & $\begin{array}{c}-0.229^{* *} \\
(0.103)\end{array}$ & $\begin{array}{c}-0.210^{* *} \\
(0.0952)\end{array}$ & $\begin{array}{c}-0.0394^{* * *} \\
(0.0147)\end{array}$ & $\begin{array}{c}-0.224^{* *} \\
(0.103)\end{array}$ \\
\hline inflation & $\begin{array}{c}0.000622 \\
(0.000406)\end{array}$ & $\begin{array}{c}0.000615 \\
(0.000396)\end{array}$ & $\begin{array}{c}0.000419 \\
(0.000314)\end{array}$ & $\begin{array}{c}0.000618 \\
(0.000408)\end{array}$ & $\begin{array}{c}0.000610 \\
(0.000400)\end{array}$ & $\begin{array}{c}0.000610 \\
(0.000401)\end{array}$ & $\begin{array}{c}0.000381 \\
(0.000304)\end{array}$ & $\begin{array}{c}5.45 \mathrm{e}-05^{* * *} \\
(3.54 \mathrm{e}-06)\end{array}$ & $\begin{array}{c}0.000629 \\
(0.000405)\end{array}$ \\
\hline popgrowth & $\begin{array}{r}-0.0884 \\
(1.633)\end{array}$ & $\begin{array}{l}-0.619 \\
(1.614)\end{array}$ & $\begin{array}{r}-0.0309 \\
(1.599)\end{array}$ & $\begin{array}{l}-0.259 \\
(1.681)\end{array}$ & $\begin{array}{l}-0.237 \\
(1.632)\end{array}$ & $\begin{array}{l}-0.331 \\
(1.677)\end{array}$ & $\begin{array}{l}-0.133 \\
(1.590)\end{array}$ & $\begin{array}{c}0.151 \\
(0.188)\end{array}$ & $\begin{array}{c}-0.116 \\
(1.638)\end{array}$ \\
\hline natural_hazard & $\begin{array}{c}-1.774^{*} \\
(1.001)\end{array}$ & $\begin{array}{l}-1.831^{*} \\
(1.016)\end{array}$ & $\begin{array}{l}-1.536 \\
(1.032)\end{array}$ & $\begin{array}{l}-1.728 \\
(1.108)\end{array}$ & $\begin{array}{l}-1.744 \\
(1.095)\end{array}$ & $\begin{array}{l}-1.738 \\
(1.096)\end{array}$ & $\begin{array}{l}-1.531 \\
(1.025)\end{array}$ & $\begin{array}{l}-0.0686 \\
(0.193)\end{array}$ & $\begin{array}{c}-1.764^{*} \\
(1.018)\end{array}$ \\
\hline caadp & $\begin{array}{c}-5.570^{* * *} \\
(1.496)\end{array}$ & $\begin{array}{c}-5.683^{* * *} \\
(1.500)\end{array}$ & $\begin{array}{c}-5.448 * * * \\
(1.361)\end{array}$ & $\begin{array}{c}-6.161^{* * *} \\
(1.428)\end{array}$ & $\begin{array}{c}-6.114 * * * \\
(1.369)\end{array}$ & $\begin{array}{c}-6.075 * * * \\
(1.379)\end{array}$ & $\begin{array}{c}-5.256^{* * *} \\
(1.378)\end{array}$ & $\begin{array}{l}0.0131 \\
(0.190)\end{array}$ & $\begin{array}{c}-5.626^{* * *} \\
(1.473)\end{array}$ \\
\hline northafrica & $\begin{array}{c}-30.80 * * * \\
(2.737)\end{array}$ & & $\begin{array}{c}-25.93^{* * *} \\
(4.863)\end{array}$ & $\begin{array}{c}-31.02 * * * \\
(2.924)\end{array}$ & $\begin{array}{c}-29.94 * * * \\
(3.124)\end{array}$ & $\begin{array}{c}-29.67^{* * *} \\
(3.041)\end{array}$ & $\begin{array}{c}-24.68 * * * \\
(5.333)\end{array}$ & $\begin{array}{c}0.933^{* * *} \\
(0.253)\end{array}$ & $\begin{array}{c}-31.14^{* * *} \\
(2.954)\end{array}$ \\
\hline eastafrica & $\begin{array}{l}-2.603 \\
(6.452)\end{array}$ & & $\begin{array}{l}-0.360 \\
(7.023)\end{array}$ & $\begin{array}{l}-2.459 \\
(6.585)\end{array}$ & $\begin{array}{l}-2.077 \\
(6.258)\end{array}$ & $\begin{array}{l}-2.152 \\
(6.233)\end{array}$ & $\begin{array}{c}2.391 \\
(7.147)\end{array}$ & $\begin{array}{c}0.404 \\
(0.386)\end{array}$ & $\begin{array}{l}-2.850 \\
(6.521)\end{array}$ \\
\hline westafrica & $\begin{array}{c}-13.69 * * * \\
(3.092)\end{array}$ & & $\begin{array}{c}-12.97^{* * *} \\
(2.820)\end{array}$ & $\begin{array}{c}-13.66^{* * *} \\
(3.164)\end{array}$ & $\begin{array}{c}-13.43^{* * *} \\
(3.044)\end{array}$ & $\begin{array}{c}-13.45^{* * *} \\
(3.013)\end{array}$ & $\begin{array}{c}-10.48^{* * *} \\
(3.776)\end{array}$ & $\begin{array}{c}0.155 \\
(0.249)\end{array}$ & $\begin{array}{c}-13.85 * * * \\
(3.172)\end{array}$ \\
\hline southernafrica & $\begin{array}{l}-7.917 \\
(4.903)\end{array}$ & & $\begin{array}{l}-5.832 \\
(5.261)\end{array}$ & $\begin{array}{l}-8.165^{*} \\
(4.887)\end{array}$ & $\begin{array}{l}-7.177 \\
(5.372)\end{array}$ & $\begin{array}{l}-7.315 \\
(5.122)\end{array}$ & $\begin{array}{l}-4.081 \\
(5.530)\end{array}$ & $\begin{array}{c}0.697 \\
(0.448)\end{array}$ & $\begin{array}{c}-8.179 * \\
(4.889)\end{array}$ \\
\hline Constant & $\begin{array}{c}38.01 * * * \\
(4.406)\end{array}$ & $\begin{array}{c}27.79 * * * \\
(3.748)\end{array}$ & $\begin{array}{c}58.90^{* * *} \\
(17.18)\end{array}$ & $\begin{array}{c}38.14^{* * *} \\
(4.488)\end{array}$ & $\begin{array}{c}38.25^{* * *} \\
(4.458)\end{array}$ & $\begin{array}{c}38.48^{* * *} \\
(4.567)\end{array}$ & $\begin{array}{c}46.53^{* * *} \\
(7.619)\end{array}$ & $\begin{array}{c}-1.171^{* *} \\
(0.473)\end{array}$ & $\begin{array}{c}37.90^{* * *} \\
(4.381)\end{array}$ \\
\hline $\begin{array}{l}\text { Observations } \\
\text { R-squared }\end{array}$ & 670 & $\begin{array}{c}670 \\
0.132\end{array}$ & 657 & 657 & 657 & 657 & 639 & 645 & 670 \\
\hline Number of id & 37 & 37 & 37 & 37 & 37 & 37 & 36 & 37 & 37 \\
\hline
\end{tabular}

VARIABLES under_nourishment under_nourishment under_nourishment $\quad$ under_nourishment under_nourishment under_nourishment under_nourishment D.under_nourishment under_nourishment 
Note : Columns 1 and 2 show random- and fixed-effects specifications of the baseline model with agricultural spending as a share of total spending. Columns $3-7$ show estimations alternately using the amount of public agricultural spending in log, public agricultural spending to GDP, per capita public agricultural spending, public agricultural spending per rural population and public agricultural spending per acre instead of share of agriculture in total public spending. Column 8 shows regression of the differenced under-nourishment indicator. Column 9 shows estimation using squared values of share of agriculture in total spending. Robust standard errors in parentheses.

${ }^{* * *} p<0.01, * * p<0.05, * p<0.1$

Table 6. Food security and public agricultural spending - time dimension
(1)
(2)
(3)
(4)
(5)
(6)

(7)

(8)

\begin{tabular}{|c|c|c|c|c|c|c|c|c|}
\hline VARIABLES & under_nourishment & under_nourishment & under_nourishment & under_nourishment & under_nourishment & under_nourishment & under_nourishment & under_nourishment \\
\hline \multirow{2}{*}{ l.agshareinspending } & -0.0738 & & & & & & & \\
\hline & $(0.518)$ & & & & & & & \\
\hline \multirow[t]{2}{*}{ |2.agshareinspending } & & -0.0524 & & & & & & \\
\hline & & $(0.524)$ & & & & & & \\
\hline \multirow[t]{2}{*}{ |3.agshareinspending } & & & 0.0547 & & & & & \\
\hline & & & $(0.472)$ & & & & & \\
\hline \multirow[t]{2}{*}{ agshareinspending } & & & & -0.111 & 0.737 & -0.333 & $-0.567 *$ & 0.00350 \\
\hline & & & & $(0.521)$ & $(0.568)$ & $(0.420)$ & $(0.341)$ & $(0.463)$ \\
\hline \multirow[t]{2}{*}{ 1.caadp } & & & & -2.754 & & & & \\
\hline & & & & $(1.714)$ & & & & \\
\hline \multirow[t]{2}{*}{ caadp * agshareinspending } & & & & $-1.934 * * *$ & & & & \\
\hline & & & & $(0.643)$ & & & & \\
\hline \multirow[t]{2}{*}{ gdpgrowth } & $-0.196 * *$ & $-0.139 * *$ & -0.0874 & $-0.223 * *$ & $-0.0931 *$ & 0.0311 & -0.0766 & $-0.0795^{*}$ \\
\hline & $(0.0856)$ & $(0.0695)$ & $(0.0668)$ & $(0.103)$ & $(0.0536)$ & $(0.110)$ & $(0.0786)$ & $(0.0416)$ \\
\hline \multirow[t]{2}{*}{ inflation } & 0.000663 & 0.000712 & $0.00910^{* * *}$ & 0.000623 & $0.000373^{* * *}$ & 0.0704 & -0.0215 & -0.0430 \\
\hline & $(0.000464)$ & $(0.000504)$ & $(0.000344)$ & $(0.000406)$ & $(0.000115)$ & $(0.0965)$ & $(0.0809)$ & $(0.0339)$ \\
\hline \multirow[t]{2}{*}{ popgrowth } & 0.179 & 0.556 & 1.207 & -0.0475 & -1.577 & 3.257 & 1.816 & $2.801^{* *}$ \\
\hline & $(1.724)$ & $(1.757)$ & (1.631) & $(1.608)$ & $(1.712)$ & (2.044) & (1.595) & $(1.183)$ \\
\hline \multirow[t]{2}{*}{ natural_hazard } & $-1.999 *$ & $-1.539 *$ & -0.934 & -1.596 & $-1.923 *$ & 0.269 & $1.077^{* *}$ & 0.331 \\
\hline & $(1.061)$ & $(0.864)$ & $(0.735)$ & $(1.022)$ & (1.114) & $(0.445)$ & $(0.533)$ & $(0.470)$ \\
\hline \multirow[t]{2}{*}{ caadp } & $-5.410 * * *$ & $-5.486 * * *$ & $-5.407 * * *$ & & & $-2.823 * * *$ & $-2.538 * * *$ & $-0.737^{*}$ \\
\hline & (1.429) & $(1.346)$ & (1.321) & & & $(0.660)$ & $(0.721)$ & $(0.415)$ \\
\hline \multirow[t]{2}{*}{ northafrica } & $-30.00 * * *$ & $-29.17^{* * *}$ & $-27.88 * * *$ & $-30.74 * * *$ & $-35.32^{* * *}$ & $-21.04 * * *$ & $-22.87^{* * *}$ & $-28.27 * * *$ \\
\hline & $(2.983)$ & (3.285) & $(3.452)$ & $(2.713)$ & $(2.875)$ & $(4.314)$ & $(4.168)$ & (1.033) \\
\hline \multirow[t]{2}{*}{ eastafrica } & -2.329 & -2.429 & -2.415 & -2.595 & -5.840 & -0.409 & 0.683 & $-8.175^{*}$ \\
\hline & (6.300) & (6.111) & $(5.888)$ & (6.436) & (7.621) & (5.254) & (6.165) & $(4.285)$ \\
\hline
\end{tabular}




\begin{tabular}{|c|c|c|c|c|c|c|c|c|}
\hline westafrica & $\begin{array}{c}-13.48^{* * *} \\
(3.228)\end{array}$ & $\begin{array}{c}-13.29^{* * *} \\
(3.493)\end{array}$ & $\begin{array}{c}-13.02^{* * *} \\
(3.715)\end{array}$ & $\begin{array}{c}-13.70^{* * *} \\
(3.058)\end{array}$ & $\begin{array}{c}-16.02^{* * *} \\
(2.972)\end{array}$ & $\begin{array}{c}-11.57^{* * *} \\
(4.285)\end{array}$ & $\begin{array}{c}-11.18^{* *} \\
(4.533)\end{array}$ & $\begin{array}{c}-20.08^{* * *} \\
(3.159)\end{array}$ \\
\hline \multirow[t]{2}{*}{ southernafrica } & -7.339 & -6.830 & -5.793 & -7.898 & $-12.31 * *$ & -2.563 & -2.965 & $-8.924 * *$ \\
\hline & (4.849) & $(4.891)$ & $(4.701)$ & $(4.875)$ & (6.048) & (5.494) & $(5.716)$ & $(4.401)$ \\
\hline \multirow[t]{2}{*}{ Constant } & $36.58^{* * *}$ & $34.94^{* * *}$ & $32.28 * * *$ & $37.83^{* * *}$ & $43.24^{* * *}$ & $22.18^{* * *}$ & $27.23^{* * *}$ & $29.79 * * *$ \\
\hline & $(4.714)$ & (4.939) & $(4.863)$ & $(4.331)$ & $(4.600)$ & (6.392) & (5.494) & $(2.230)$ \\
\hline Observations & 674 & 677 & 660 & 670 & 398 & 272 & 168 & 104 \\
\hline Number of id & 37 & 37 & 38 & 37 & 34 & 37 & 37 & 29 \\
\hline
\end{tabular}


Table 7. Food security and public agricultural spending - spending threshold

(1) (2) (3) (4)

VARIABLES under_nourishment under_nourishment under_nourishment under_nourishment

\begin{tabular}{|c|c|c|c|c|}
\hline agshareinspending & -0.557 & $\begin{array}{l}-0.227 \\
0.808\end{array}$ & & \\
\hline Inagexp & & & $\begin{array}{c}-3.610^{* *} \\
(1.619)\end{array}$ & $\begin{array}{c}-1.156 * * \\
(0.501)\end{array}$ \\
\hline gdpgrowth & $\begin{array}{l}-0.0776 \\
(0.151)\end{array}$ & $\begin{array}{l}-0.310 \\
(0.238)\end{array}$ & $\begin{array}{c}-0.246 * * * \\
(0.0820)\end{array}$ & $\begin{array}{l}-0.0157 \\
(0.134)\end{array}$ \\
\hline inflation & $\begin{array}{r}-0.00396 \\
(0.0304)\end{array}$ & $\begin{array}{l}0.0363 \\
(0.102)\end{array}$ & $\begin{array}{c}0.0366 \\
(0.0412)\end{array}$ & $\begin{array}{r}-0.00490 \\
(0.0191)\end{array}$ \\
\hline popgrowth & $\begin{array}{c}-0.842 \\
(2.290)\end{array}$ & $\begin{array}{l}-1.816 \\
(2.449)\end{array}$ & $\begin{array}{l}-0.270 \\
(1.732)\end{array}$ & $\begin{array}{c}0.775 \\
(0.929)\end{array}$ \\
\hline natural_hazard & $\begin{array}{c}-3.080 * * * \\
(1.051)\end{array}$ & $\begin{array}{c}-1.844^{* *} \\
(0.823)\end{array}$ & $\begin{array}{l}-1.279 * \\
(0.693)\end{array}$ & $\begin{array}{l}-0.0399 \\
(0.910)\end{array}$ \\
\hline caadp & $\begin{array}{c}-6.355^{* * *} \\
(1.626)\end{array}$ & $\begin{array}{c}-4.991 * * * \\
(1.661)\end{array}$ & $\begin{array}{c}-4.869 * * * \\
(1.570)\end{array}$ & $\begin{array}{c}-4.147^{* * *} \\
(1.302)\end{array}$ \\
\hline northafrica & $\begin{array}{c}-40.48^{* * *} \\
(2.433)\end{array}$ & $\begin{array}{c}-37.82^{* * *} \\
(3.768)\end{array}$ & $\begin{array}{c}-16.52^{* *} \\
(7.494)\end{array}$ & $\begin{array}{c}-34.07^{* * *} \\
(2.774)\end{array}$ \\
\hline eastafrica & $\begin{array}{l}-9.989 \\
(6.370)\end{array}$ & $\begin{array}{c}0.970 \\
(4.916)\end{array}$ & $\begin{array}{c}5.636 \\
(8.023)\end{array}$ & $\begin{array}{l}-3.984 \\
(3.407)\end{array}$ \\
\hline westafrica & $\begin{array}{c}-24.51 * * * \\
(3.773)\end{array}$ & $\begin{array}{c}-21.49 * * * \\
(4.042)\end{array}$ & $\begin{array}{l}-9.584 \\
(6.576)\end{array}$ & $\begin{array}{c}-26.88^{* * *} \\
(3.195)\end{array}$ \\
\hline southernafrica & $\begin{array}{c}-15.14^{* * *} \\
(3.589)\end{array}$ & $\begin{array}{c}-12.37^{* * *} \\
(4.686)\end{array}$ & $\begin{array}{c}1.853 \\
(7.577)\end{array}$ & $\begin{array}{l}-13.11^{*} \\
(6.819)\end{array}$ \\
\hline Constant & $\begin{array}{c}48.83 * * * \\
(4.652)\end{array}$ & $\begin{array}{c}47.79 * * * \\
(7.086)\end{array}$ & $\begin{array}{c}97.05 * * * \\
(28.09)\end{array}$ & $\begin{array}{c}62.50 * * * \\
(11.53)\end{array}$ \\
\hline Observations & 358 & 175 & 363 & 186 \\
\hline Number of id & 30 & 22 & 28 & 19 \\
\hline
\end{tabular}

Note :

Column 1 shows estimations for subsample of countries with above median agricultural spending as a proportion of total spending. Column 2 shows estimations for top $25 \%$ countries in the agricultural spending share distribution. Column 3 shows estimations for subsample of countries with above median amount of agricultural spending. Column 4 shows estimations for top $25 \%$ countries in the agricultural spending amount distribution.

Robust standard errors in parentheses

*** $p<0.01,{ }^{* *} p<0.05, * p<0.1$ 
Table 8. Food security and public agricultural spending - space dimension

\begin{tabular}{|c|c|c|c|c|c|}
\hline & (1) & $(2)$ & (3) & (4) & (5) \\
\hline VARIABLES & under_nourishment & under_nourishment & under_nourishment & under_nourishment & under_nourishment \\
\hline \multirow{2}{*}{ agshareinspending } & $-1.443^{* *}$ & -0.206 & -0.393 & $7.748 * * *$ & 2.579 \\
\hline & $(0.592)$ & $(0.718)$ & (1.109) & $(2.707)$ & $(2.381)$ \\
\hline \multirow[t]{2}{*}{ gdpgrowth } & -0.0297 & -0.0929 & -0.216 & -0.430 & $-0.549 * * *$ \\
\hline & $(0.0371)$ & $(0.0573)$ & $(0.274)$ & $(0.422)$ & (0.139) \\
\hline \multirow[t]{2}{*}{ inflation } & $-0.0389 * * *$ & 0.0289 & $0.00882 * * *$ & -0.263 & $0.000233 * * *$ \\
\hline & $(0.0116)$ & $(0.0432)$ & $(0.000592)$ & $(0.178)$ & (8.98e-05) \\
\hline \multirow[t]{2}{*}{ popgrowth } & 0.758 & -1.561 & 1.688 & $12.68 * * *$ & $-5.151 * *$ \\
\hline & $(0.648)$ & (1.334) & (3.093) & (3.083) & $(2.394)$ \\
\hline \multirow[t]{2}{*}{ natural_hazard } & & -1.298 & 0.0930 & -2.655 & $-5.876 * * *$ \\
\hline & & $(1.439)$ & (3.359) & (3.325) & $(1.748)$ \\
\hline \multirow[t]{2}{*}{ caadp } & & $-6.426 * * *$ & 2.422 & -2.503 & -1.413 \\
\hline & & $(1.350)$ & (3.934) & $(2.146)$ & $(2.605)$ \\
\hline \multirow[t]{2}{*}{ Constant } & $7.230 * * *$ & $27.56 * * *$ & $25.25^{* * *}$ & $-5.148^{*}$ & $50.29 * * *$ \\
\hline & $(1.338)$ & $(4.260)$ & (9.071) & $(2.881)$ & $(5.000)$ \\
\hline Observations & 74 & 240 & 162 & 128 & 66 \\
\hline Number of id & 4 & 13 & 9 & 7 & 4 \\
\hline
\end{tabular}

Note : Columns 1 to 5 show estimations pertaining to North Africa, West Africa, Southern Africa, East Africa and Central Africa respectively.

Robust standard errors in parentheses

$* * * p<0.01, * * p<0.05, * p<0.1$ 
Table 9. Food security and public agricultural spending - dimensions of food security

\begin{tabular}{|c|c|c|c|c|}
\hline & $(1)$ & (2) & (3) & $(4)$ \\
\hline VARIABLES & Availability & Access & Stability & Utilization \\
\hline \multirow[t]{2}{*}{ agshareinspending } & -0.566 & -95.43 & 0.130 & 0.00501 \\
\hline & $(0.548)$ & (74.67) & $(0.401)$ & $(0.438)$ \\
\hline \multirow[t]{2}{*}{ gdpgrowth } & $0.181 * *$ & $12.45^{* * *}$ & -0.00467 & $0.112 * *$ \\
\hline & $(0.0713)$ & (4.695) & $(0.0351)$ & $(0.0493)$ \\
\hline \multirow[t]{2}{*}{ inflation } & $-0.00575 * * *$ & $-3.733^{*}$ & $-7.59 e-05$ & -0.000300 \\
\hline & $(0.000155)$ & $(2.182)$ & (5.57e-05) & (0.000227) \\
\hline \multirow[t]{2}{*}{ popgrowth } & 0.162 & 194.8 & $1.511^{* * *}$ & $-3.938 * *$ \\
\hline & $(1.423)$ & (157.9) & $(0.544)$ & $(1.568)$ \\
\hline \multirow[t]{2}{*}{ natural_hazard } & $1.765^{* *}$ & -81.78 & 1.153 & $1.178 * * *$ \\
\hline & $(0.816)$ & (81.97) & $(0.704)$ & $(0.434)$ \\
\hline \multirow[t]{2}{*}{ caadp } & $6.487^{* * *}$ & 17.09 & $1.652^{*}$ & $3.787 * * *$ \\
\hline & $(1.303)$ & $(52.65)$ & $(0.848)$ & $(0.754)$ \\
\hline \multirow[t]{2}{*}{ northafrica } & $42.82 * * *$ & 261.5 & $17.44^{* *}$ & $50.09 * * *$ \\
\hline & $(4.216)$ & $(226.3)$ & (7.061) & (7.891) \\
\hline \multirow[t]{2}{*}{ eastafrica } & 4.999 & 83.51 & 1.771 & 7.162 \\
\hline & $(5.224)$ & $(126.5)$ & (1.679) & $(11.74)$ \\
\hline \multirow[t]{2}{*}{ westafrica } & $14.83 * * *$ & 16.41 & $3.594 * * *$ & -4.580 \\
\hline & (3.032) & $(85.63)$ & $(0.984)$ & $(6.707)$ \\
\hline \multirow[t]{2}{*}{ southernafrica } & $7.731 * *$ & 481.8 & $5.029 * * *$ & $12.49 *$ \\
\hline & (3.730) & $(362.0)$ & $(1.515)$ & $(7.364)$ \\
\hline \multirow[t]{2}{*}{ Constant } & $94.16 * * *$ & -291.1 & -0.271 & $33.37^{* * *}$ \\
\hline & $(3.828)$ & $(326.8)$ & $(1.464)$ & $(7.082)$ \\
\hline Observations & 654 & 359 & 663 & 659 \\
\hline Number of id & 36 & 35 & 37 & 37 \\
\hline
\end{tabular}

Note :

Columns 1 - 4 show estimations pertaining to indicators of the four food security dimensions: Average dietary energy supply adequacy (availability), Food price index (access), Per capita food production variability (stability), and percentage of population with access to improved sanitation facilities (utilization).

Robust standard errors in parentheses

$* * * p<0.01, * * p<0.05, * p<0.1$ 


\section{(1) \\ (2) \\ (3)}

VARIABLES

Inagrirespending

agriregdp

agrirepc

agriresearchers

L.Inagrirespending

L2.Inagrirespending

L3.Inagrirespending

gdpgrowth
inflation

popgrowth

natural_hazard

caadp

northafrica

eastafrica

westafrica

southernafrica

Constant

Observations

Number of id

under_nourishment under_nourishment

$-3.348 *$

(1.716)

$-0.627$

(0.936)

\begin{abstract}
$-0.283$
(0.458)
\end{abstract}

$-0.0506 * * *$

(0.0144)
$-2.795^{*}$

(1.611)

$-2.743^{*}$

(1.647)

\begin{tabular}{|c|c|c|c|}
\hline & & & $\begin{array}{l}-2.555 \\
(1.727)\end{array}$ \\
\hline-0.0425 & -0.0596 & -0.0520 & 0.0117 \\
\hline$(0.0844)$ & $(0.0653)$ & $(0.0588)$ & $(0.0723)$ \\
\hline-0.0248 & -0.00296 & 0.0268 & $0.0933^{*}$ \\
\hline$(0.0496)$ & $(0.0482)$ & $(0.0568)$ & $(0.0546)$ \\
\hline-2.321 & -1.416 & -0.805 & -0.0924 \\
\hline (1.984) & $(2.136)$ & (2.101) & (1.775) \\
\hline-0.424 & -0.839 & $-0.869 *$ & -0.451 \\
\hline$(0.629)$ & $(0.628)$ & $(0.496)$ & $(0.573)$ \\
\hline$-5.165 * * *$ & $-5.059 * * *$ & $-4.884 * * *$ & $-4.543 * * *$ \\
\hline$(1.162)$ & (1.110) & $(0.970)$ & $(0.925)$ \\
\hline$-19.44^{* * *}$ & $-18.56 * * *$ & $-19.52^{* * *}$ & $-20.52^{* * *}$ \\
\hline (5.920) & $(6.534)$ & (6.581) & (6.654) \\
\hline 3.540 & 5.653 & 4.378 & 2.733 \\
\hline (7.307) & $(8.566)$ & $(8.480)$ & (8.314) \\
\hline-8.602 & -7.340 & -8.386 & -9.489 \\
\hline$(6.336)$ & $(6.843)$ & $(6.864)$ & (6.919) \\
\hline-3.751 & -0.636 & -0.798 & -1.015 \\
\hline$(7.427)$ & (8.377) & $(8.351)$ & $(8.291)$ \\
\hline $37.57^{* * *}$ & $39.40 * * *$ & $38.21^{* * *}$ & $35.74 * * *$ \\
\hline (8.019) & (8.939) & $(8.962)$ & $(8.545)$ \\
\hline 498 & 502 & 507 & 507 \\
\hline
\end{tabular}

(6)

(7)

under_nourishment 
Table 11. Food security and public agricultural spending - Additional controls

\section{(1) \\ (3)}

(4)

(5)

VARIABLES

agshareinspending

rule_of_law

$-0.743$

(0.465)

$-1.993$

(1.681)

attacks

intensity_level

rural_pop_share

foodproductionindex

gdpgrowth

inflation

$$
-0.0772 *
$$

(0.0412)

$0.00743^{* * *}$

(0.000226)

popgrowth

natural_hazard

$2.386^{* *}$

(1.153)

$-1.062^{* *}$

(0.492)

caadp

$-4.579 * * *$

(0.993)

northafrica

$-23.15 * * *$

(3.316)

eastafrica

0.748

(5.693)

westafrica

$-11.41 * * *$

(3.505)

southernafrica

$-2.926$

(4.452)

Constant

$26.52^{* * *}$

Observations

(4.574)

432

37
0.0809

(0.961)

0.00785

(0.00563)

2.134

(1.637)

$-0.658$

(1.107)

(1.637)

$0.732^{* * *}$

(0.282)

$-0.287^{* *}$

(0.123)

$0.000467 *$

(0.000256)

1.234

(2.355)

$-2.822 * *$

(1.099)

$-7.201 * * *$

(1.782)

$-31.01 * * *$

(3.578)

0.140

(5.145)

$-14.80^{* * *}$

(3.132)

$-8.478$

(6.593)

$36.11^{* * *}$

(5.652)
$-0.328 * *$

(0.149)

$0.00480^{* * *}$

(0.000348)

3.377

(7.603)

$-2.452^{* *}$

(0.970)

$-9.191^{* * *}$

(3.374)

$-28.07^{* * *}$

(7.068)

5.931

(8.395)

$-14.34 * * *$

(4.046)

8.467

(5.882)

28.44

(17.47)
$-0.149 *$

(0.0831)

0.000435

(0.000283)

$-1.636$

(1.692)

$-1.242$

(1.120)

$-2.764$

(1.828)

$-23.97 * * *$

(5.540)

$-17.96 * *$

(8.024)

$-18.82^{* * *}$

(4.581)

$-15.70^{* * *}$

(6.025)

0.854

(15.01)

670
Number of id

30

37
$-0.182^{* * *}$

(0.0424)

$-0.0426$

(0.0702)

$0.000734 * * *$

(0.000210)

$-1.024$

(1.032)

$-0.739$

(0.870)

1.565

(1.676)

$-32.96 * * *$

(2.702)

$-3.630$

(6.193)

$-14.26 * * *$

(3.488)

$-7.530$

(5.146)

$55.98^{* * *}$

(5.066)

Note:

Columns 1 - 5 show estimations including indicators for rule of law, terrorist attacks, armed conflict, proportion of rural population, and food production index respectively.

Robust standard errors in parentheses

*** $p<0.01,{ }^{* *} p<0.05, * p<0.1$ 
Table 12. Food security and public agricultural spending - Alternative econometric techniques

\begin{tabular}{|c|c|c|c|c|c|}
\hline & $(1)$ & $(2)$ & (3) & (4) & (5) \\
\hline VARIABLES & under_nourishment & under_nourishment & under_nourishment & under_nourishment & under_nourishm \\
\hline \multirow[t]{2}{*}{ agshareinspending } & -0.0746 & -0.161 & 0.0529 & -0.0746 & 0.00976 \\
\hline & $(0.222)$ & $(0.531)$ & $(0.0534)$ & $(0.364)$ & $(0.0522)$ \\
\hline \multirow[t]{2}{*}{ L.under_nourishment } & & & $0.907 * * *$ & & $0.890 * * *$ \\
\hline & & & $(0.00676)$ & & $(0.00563)$ \\
\hline \multirow[t]{2}{*}{ gdpgrowth } & -0.140 & $-0.223 * *$ & $-0.0444 * * *$ & $-0.140 *$ & $-0.0467 * * *$ \\
\hline & $(0.132)$ & $(0.103)$ & $(0.00580)$ & $(0.0833)$ & $(0.00568)$ \\
\hline \multirow[t]{2}{*}{ inflation } & 0.000630 & 0.000622 & $7.02 \mathrm{e}-05^{* *}$ & 0.000630 & $7.05 e-05 * *$ \\
\hline & $(0.000460)$ & $(0.000406)$ & $(3.18 \mathrm{e}-05)$ & $(0.000431)$ & $(3.16 e-05)$ \\
\hline \multirow[t]{2}{*}{ popgrowth } & $7.364^{* * *}$ & -0.0884 & $0.946 * * *$ & $7.364^{* * *}$ & $0.835^{* * *}$ \\
\hline & $(0.435)$ & $(1.633)$ & $(0.118)$ & $(0.606)$ & $(0.112)$ \\
\hline \multirow[t]{2}{*}{ natural_hazard } & $-1.841^{*}$ & $-1.774^{*}$ & -0.0699 & -1.841 & -0.0988 \\
\hline & $(1.046)$ & $(1.001)$ & $(0.101)$ & $(1.344)$ & $(0.0972)$ \\
\hline \multirow[t]{2}{*}{ caadp } & $-3.399 * * *$ & $-5.570 * * *$ & $-0.414 * * *$ & $-3.399 * *$ & $-0.463 * * *$ \\
\hline & $(0.913)$ & $(1.496)$ & $(0.110)$ & $(1.431)$ & $(0.0973)$ \\
\hline \multirow[t]{2}{*}{ northafrica } & $-24.14 * * *$ & $-30.80 * * *$ & 0 & $-24.14 * * *$ & $20.06 * * *$ \\
\hline & (1.159) & $(2.737)$ & (0) & (1.939) & $(0.825)$ \\
\hline \multirow[t]{2}{*}{ eastafrica } & $-6.062 * * *$ & -2.603 & 0 & $-6.062 * * *$ & $4.904^{* * *}$ \\
\hline & $(1.070)$ & $(6.452)$ & (0) & $(1.656)$ & $(0.483)$ \\
\hline \multirow[t]{2}{*}{ westafrica } & $-17.71 * * *$ & $-13.69 * * *$ & 0 & $-17.71^{* * *}$ & $-1.151^{* * *}$ \\
\hline & (1.091) & (3.092) & (0) & (1.533) & $(0.352)$ \\
\hline \multirow[t]{2}{*}{ southernafrica } & $-6.146^{* * *}$ & -7.917 & 0 & $-6.146 * * *$ & $4.989 * * *$ \\
\hline & $(1.132)$ & $(4.903)$ & (0) & $(1.628)$ & $(0.535)$ \\
\hline \multirow[t]{2}{*}{ Constant } & $20.09 * * *$ & $38.01 * * *$ & -0.181 & $20.09 * * *$ & $-3.339 * * *$ \\
\hline & $(0.933)$ & $(4.406)$ & (0.319) & $(1.956)$ & $(0.452)$ \\
\hline Observations & 670 & 670 & 606 & 670 & 645 \\
\hline Number of year & 22 & & & & \\
\hline Number of id & & 37 & 36 & 37 & 37 \\
\hline \multicolumn{6}{|c|}{ Note: } \\
\hline \multirow{3}{*}{\multicolumn{6}{|c|}{$\begin{array}{l}\text { Columns } 1 \text { and } 2 \text { show models including time and country-fixed effects respectively. } \\
\text { Columns } 3 \text { - } 5 \text { show Arellano and Bond, GLS and System GMM estimations for the baseline specification. } \\
\text { Robust standard errors in parentheses. }\end{array}$}} \\
\hline & & & & & \\
\hline & & & & & \\
\hline \multicolumn{6}{|c|}{$* * * p<0.01,{ }^{* *} p<0.05, * p<0.1$} \\
\hline
\end{tabular}

